\title{
17
}

\section{Analysing e-business Models}

\author{
Jonas Hedman and Thomas Kalling \\ Department of Informatics, School of Economics and Management, Lund University and \\ Institute of Economic Research, School of Economics and Management, Lund University
}

\begin{abstract}
The business model concept is becoming increasingly popular within ebusinesses and e-business research. However, the concept is often used relatively independently from theory, meaning model components and their interrelations are relatively obscure. This paper analysis three e-business models taxonomies based on a generic business model, which include customers and competitors, the offering, activities and organisation, resources and factor market interactions. The longitudinal processes and actions by which business models evolve are also included. The result of the analysis shows that most of the e-business models only addresses customers and the offering. Other important aspects of any business, e.g. activates and resource, are not addressed. In sum, e-business models, as they appear, in literature are formal descriptions of how businesses can use the Internet to leverage their offering, without any casual relationships between components, e.g. that the offering requires some activities to be performed by the organisation in order to deliver a offering to a market.
\end{abstract}

Keywords: e-business models, analysis, business models

\section{INTRODUCTION}

Business model is a term that is particularly popular among e-businesses and within research on e-businesses (e.g. Timmers, 1998; Amit and Zott, 2001; Allen and Fjermestad, 2001; Afuah and Tucci, 2001; Applegate, 2001; Cheng et al. 2001; Rayport and Jaworski, 2001; Weill and Vitale, 2001; Rappa, 2002). The term business model is used to describe the key components of a given business and/or to describe how businesses use the Internet to interact with each other and how value is created for customers, suppliers, partners, employees, and other stakeholders (Applegate, 2001, p 2).

\footnotetext{
The original version of this chapter was revised: The copyright line was incorrect. This has been corrected. The Erratum to this chapter is available at DOI: 10.1007/978-0-387-35617-4_48 
The empirical use of the concept has been criticised for being unclear, superficial and not theoretically grounded (Porter, 2001) and lack of scientific method (Hedman and Kalling, 2001). Furthermore, most of the research on business models is based on e-business, not business, which makes it difficult to generalise the components and their causalities to more traditional forms of business models. The e-business research has so far provided components and descriptions of e-business models, but it could benefit from a broader use of business and strategy theory, which would provide more content as well as a clearer coherence in terms of causality in their models.

The purpose of this paper is to analyse e-business models. This will be done, based on a theoretically generic business model, which includes the finer aspects of strategy, e.g. resource-bases, activities, organisational structure, products, and environmental factors. The paper is structured as follows: First, we present the generic business models that we will use in the analysis of e-business models. Then we review some of the e-business models that are presented in the literature. Following this, we analyse ebusiness models. Finally, we conclude this paper with a discussion on the contributions of the analysis.

\section{BUSINESS MODEL FRAMEWORK}

There are few integrative generic business models or strategy models that unite finer aspects business and strategy, e.g. resource-bases, activities, organisational structure, products, environmental factors etc. In fact, strategists still tend to argue about what it is that makes companies successful, e.g. whether it is firm-internal resources (Barney, 1991), whether it is successful reconfiguration of the value chain (Porter, 1985) or generic strategy (Porter, 1980). E-business research, on the other hand, has just provided components and descriptions of business models, without any clear coherence in terms of causality between the components. 


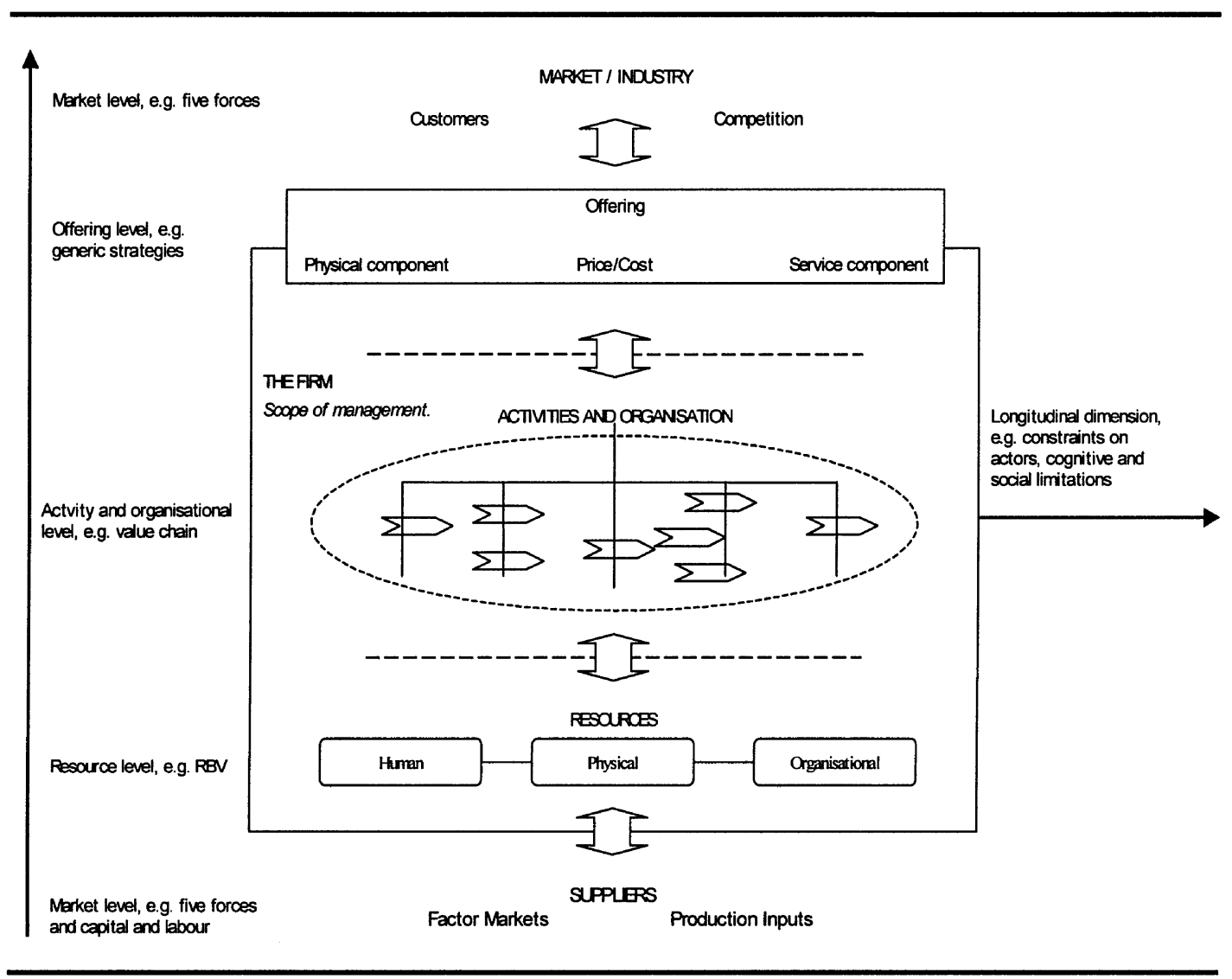

Figure 1. The Components of a Business Model, adapted from Hedman \& Kalling (2002).

Hedman and Kalling $(2001 ; 2002)$ present a generic business model based on a review of strategy theory. Their model include Industrial Organisation (I/O) (e.g. Porter, 1980; 1985), RBV (e.g. Barney, 1986; 1991), and the Process Perspective (Mintzberg, 1978; 1994; Chakravarthy and Doz, 1992; Amit and Schoemaker, 1993; Andreu and Ciborra, 1996); contemporary strategy theory (e.g. Porter, 1991; Eisenhardt and Sull, 2001). Their model includes several causally related components, starting at the product market level: 1) Customers, 2) Competitors 3) Offering, 4) Activities and Organisation, 5) Resources and 6) Factor and Production Inputs. These components are all cross-sectional and can be studied at a given point in time. To make the business model complete, they also include a longitudinal process component, to cover the dynamics of the business model over time and the cognitive and cultural constraints on change that managers have to cope with. In figure 1, it is refereed to as the Scope of management. 
Hedman and Kalling's model integrates firm-internal aspects that transform factors to resources, through activities, in a structure, to products and offerings, to market. The logic is that in order to be able to serve the product market, businesses need activities, input from the factor market (capital and labour) and the supply of raw material. The same resource-base and activities and organisation can produce different products and hence have a scope of different offerings (e.g. cars in two or more colours), but at some point during diversification, new activities are needed (e.g. cars in two or more versions) and potentially also new resources (e.g. diversification to include lorries), thus forcing the development of business models. With this view, (even a non-diversified) firm can have many different business models. However, the more profound the differences between products, the higher the probability that the businesses are organised independently from each other (cars and lorries make out distinct business units in most vehiclebased corporations). Therefore, an organisation may have several business models and a business model may include several organisations.

There are causal relations between the different components. In order to serve a particular customer segment and compete with the products within that segment, the offering must have a favourable quality/price position. In order to achieve this, firms need to offer customer-perceived quality of physical product features and service, which in turn requires effective activities (e.g. large scale, competence) and organisational structure (efficient communication and division of labour and authority). This requires human, organisational and physical resources that have to be acquired on factor markets and from suppliers of production inputs. Although not depicted graphically, external actors are potential partners or competitors in all aspects of the business: in the bundling of products (e.g. computers and software), in activities (e.g. outsourcing ICT, buying services from advertising agencies) and in the configuration of resources (e.g. banks and insurance companies share customer data bases). Change can appear both in exogenous or endogenous processes. A poor offering (e.g. too high price/quality) may initiate change programmes that result in reformed activities and a reconfigured resource base, but it can also work the other way. Firms take stock of their resource base and may find new ways to combine resources, and new ways to dispose of activities because of resource modifications. This can result in new products and improved product market positions. Therefore, change can take either direction, and the depth of change will vary. Logically it seems that resource bases are more difficult to change than products and activities. What is important though is the realisation that whatever the modification, it will affect other components of the model.

One important aspect is that the business model has to be managed and developed. This is how the process perspective is included. The model can be studied in a cross-sectional dimension (the causal dimension, vertical in 
the outline of the model) but it also evolves over time (the longitudinal dimension, horizontal in the outline of the model) as managers and people from the inside, and as customers and competitors on the outside, continues to evolve. These processes include the bridging of cognitive, cultural, political obstacles, and are issues that managers deal with on a regular basis, for all components of the model. This model incorporates RBV, I/O, and Process perspectives and solves potentially many RBV questions about what is the unit of analysis in terms of value and uniqueness. Is it the resource, the intermediate activities or the product that should be analysed? One way to approach this issue - if one is interested at all - is to use the business model. Certain parts of it may be more valuable and unique than others, be it a product feature or a particular type of knowledge, and that is what matters.

\section{E-BUSINESS MODEL RESEARCH}

As stated earlier, the business model concept is often used in e-business research. Cherian (2001) identified at least 33 business models, Applegate (2001) classified 22 e-business models, and Timmers (1998) presented eleven specific business models. Afuah and Tucci (2001, p. 45) even claim that a well-formulated business model will render a firm greater profit than its competitors. The growing body of e-business model research, empirical or conceptual, can be organised around two complimentary streams. The first stream aims to describe and define the components of a business model (Afuah and Tucci, 2001; Amit and Zott, 2001; Weill and Vitale, 2001). The other stream aims to develop descriptions of specific business models (Timmers, 1998; Rappa, 2002; Applegate, 2001).

Timmers (1998, p 4) defines a business model as: "An Architecture for the products, service and information flows, including a description of the various business activities and their roles; and A description of the potential benefits for the various business actors; and A description of the sources of revenues." Furthermore, a business model has to include marketing strategy, marketing mix, and product-market strategy. Weill and Vitale (2001) presents a similar definition: A description of the roles and relationships among a firm's consumers, customers, allies, and suppliers that identifies the major flows of product, information, and money, and the major benefits to participants." Amit and Zott (2001) presented three components of ebusiness models, including content (exchanged goods and information and the resources required to facilitate the exchange), structure (the transaction stakeholders and how they are linked), and governance of transactions (the control of the flows of goods, information and resources and the legal association form) of an e-business model. They concluded that in order to understand the factors behind value-creation in e-business (efficiency, 
complementarity, lock-in and novelty), a range of different theories had to be used and integrated into a business model. They used value chain analysis (Porter, 1985), Schumpeterian innovation (Schumpeter, 1934), RBV (Barney, 1991), strategic networks theory (Burt, 1992) and transaction cost economics (Williamson, 1975) to be able to capture the factors of e-business value creation and construct the business model. All three components are important to understand e-business models, yet what is included in each depend upon the nature of the business. Afuah and Tucci (2001) presented a list of components including customer value (distinctive offering or low cost), scope (which customer and what products/services), price (price the value), revenue sources, connected activities (interdependency between different activities within the business model), implementation (what resources are needed, e.g. structure, people, and the fit between them), capabilities (what skills are needed), and sustainability (what is difficult to imitate of the business model). Their list is applicable to both e-business models and traditional business models, but without causality between the components. Applegate's (2001) business model framework, based on I/O logic and on empirical work, consists of three components: concept, capabilities, and value. The business concept defines a business market opportunity, product and services offered, competitive dynamics, strategy to obtain a dominant position, and strategic option for evolving the business. The second component is the capabilities of an organisation, which are built and delivered through its people and partners, organisational structure, culture, operating model, marketing and sales model, management model, development model, and infrastructure model. Value is related to the performance of a business model and can be measured by return to all stakeholders, return to the organisation, market share, brand and reputation, and financial performance. The components are interdependent to each other and traditional strategic frameworks, e.g. value chain analysis, can be used to analyse a business model. The difference between previous industrial age the old economy - business model and e-business models is the different business rules and assumptions of how business is done (Applegate, 2001).

\begin{tabular}{|c|c|c|c|c|}
\hline $\begin{array}{l}\text { Afuah \& Tucci } \\
\text { (2001) }\end{array}$ & $\begin{array}{l}\text { Amit \& Zott } \\
(2001)\end{array}$ & $\begin{array}{l}\text { Applegate's } \\
(2001)\end{array}$ & $\begin{array}{l}\text { Timmers } \\
\text { (1998) }\end{array}$ & $\begin{array}{l}\text { Weill \& Vitale } \\
(2001)\end{array}$ \\
\hline $\begin{array}{l}\text { Customer value } \\
\text { Scope } \\
\text { Price } \\
\text { Revenue sources } \\
\text { Connected activities } \\
\text { Implementation } \\
\text { Capabilities } \\
\text { Sustainability }\end{array}$ & $\begin{array}{l}\text { Content } \\
\text { Structure } \\
\text { Governance }\end{array}$ & $\begin{array}{l}\text { Concept } \\
\text { Capabilities } \\
\text { Value }\end{array}$ & $\begin{array}{l}\text { Business } \\
\text { activities } \\
\text { Potential } \\
\text { benefits } \\
\text { Revenue } \\
\text { sources } \\
\text { Marketing } \\
\text { strategy } \\
\text { Marketing } \\
\text { mix }\end{array}$ & $\begin{array}{l}\text { Consumers } \\
\text { Customers } \\
\text { Allies } \\
\text { Suppliers } \\
\text { Flows of product, } \\
\text { information and } \\
\text { money }\end{array}$ \\
\hline
\end{tabular}




\begin{tabular}{lllll}
\hline $\begin{array}{l}\text { Afuah \& Tucci } \\
(2001)\end{array}$ & $\begin{array}{l}\text { Amit \& Zott } \\
(2001)\end{array}$ & $\begin{array}{l}\text { Applegate's } \\
(2001)\end{array}$ & $\begin{array}{l}\text { Timmers } \\
(1998)\end{array}$ & $\begin{array}{l}\text { Weill \& Vitale } \\
(2001)\end{array}$ \\
\hline & & Product \\
& & market & \\
& & strategy \\
\hline
\end{tabular}

Table 1. Components of e-business models

The other stream of research on business models aims to define and describe generic or specific business models that explains how businesses use the Internet to interact with each other and how value is created for customers, suppliers, partners, employees, and other stakeholders (Applegate, 2001, p 2). Applegate (2001) also argue that the role of business models is to develop a new vocabulary to describe what businesses do, since the existing vocabulary was developed for the old economy and does not explain how Internet enables businesses to create new business models and redefine the existing ones. You could compare this with traditional industry descriptions, such as manufacturing and service industries. Afuah and Tucci (2001), Timmers (1998), and Weill and Vitale (2001) present a similar view on the role of business models, but are not explicit. Weill and Vitale (2001) state that there is a finite number of business models, and describe eight ebusiness models: direct customer, full-service provider, intermediary, whole of enterprise, shared infrastructure, virtual community, value net integrator, and content provider. Timmers (1998) presents eleven generic business models e-shop, e-procurement, e-auction, e-mall, third party marketplace, virtual communities, value chain service provider, value chain integrators, collaboration platforms, and information brokerage. His classification is based on a systematic approach to identify architectures for business models. Three dimensions are used in his classification: value chain de-construction, interaction patterns (one to one or one to many), and value chain reconstruction. Rappa (2002) states that there is no single comprehensive taxonomy for classifying business and makes his own classification, including brokerage, advertising, infomediary, merchant, manufacturing, affiliate, community, subscription, and utility. Applegate (2001) presents five general categories of business models and 22 specific types of ebusiness models. The classification is based on generic market role (suppliers, producers, distributors, and customers), digital business (if the business is dependent on the Internet), and platform (whether or whether not the business is a provider of the infrastructure upon which digital business are built and operated on). In the appendix, we have summarised Applegate's (2001), Rappas' (2002), and Timmers' (1998) business models.

The e-business model research provides formal descriptions of how to conduct business and make revenues over the Internet (Rappa, 2002), but it has several shortcomings, e.g. does not address competition, causality 
between the components, and longitudinal management processes. Weill and Vitale (2001) are the only ones to mention suppliers as an essential part of a business model. Amit and Zott (2001), Timmers (1998), and Rappa (2002) are biased towards e-business. But, most of all they lack a theoretical ground, a notable exception being Amit and Zott (2001).

\section{METHOD}

This survey was based on a study of 42 e-business models from three ebusiness resources (Applegate, 2001; Rappas, 2002; and Timmers, 1998); they represent some of the most quoted and referred e-business models. The analytical framework was based on Hedman and Kalling's (2001) generic business model. The formal descriptions of the e-business models were classified into five broad categories: (i) market level, (ii) offering level, (iii) activities and organisational level, (iv) resource level, and (v) factor market level. Furthermore, each e-business model was classified regarding the causality of the components and longitudinal process components.

a) Market level concerns customers and competitors.

b) Offering level concerns the two generic strategies a firm can apply, i.e. 1) to differentiate the product so as to enable a premium price, or 2) to produce with low-cost and compete with a low price rather than quality.

c) Activities and organisational level focus on the activities of the firm and control, i.e. organisational structure, over activities.

d) Recourse level emphasises the characteristics of the underlying factors behind low-cost and differentiation and the value chain; i.e. the resources of the company.

e) Factor market level concerns capital, labour, and production inputs.

f) Causality refers to relationship between components.

g) Longitudinal process concerns the cognitive and cultural constraints on strategic development, i.e. the obstacles or resources that influence the business model evolution

\subsection{Result}

A total of 42 e-business models were analysed according to Hedman and Kalling's $(2001 ; 2002)$ business model, see table 2 for a summary of the analysis (note the numbers in table 2 refer to the corresponding e-business models in Appendix).

\begin{tabular}{lllllll}
\hline Market & Offering & $\begin{array}{l}\text { Activities } \\
\text { and } \\
\text { organisation }\end{array}$ & Resources & $\begin{array}{l}\text { Factor } \\
\text { market }\end{array}$ & $\begin{array}{l}\text { Causality } \\
\text { and } \\
\text { Longitudinal } \\
\text { process }\end{array}$ \\
\hline Corresponding & $6,7,8$, & $1,2,3$, & $14,15,16$, & $17,18,41$ & 24,34, & None
\end{tabular}




\begin{tabular}{lllllll}
\hline & Market & Offering & $\begin{array}{l}\text { Activities } \\
\text { and } \\
\text { organisation }\end{array}$ & Resources & $\begin{array}{l}\text { Factor } \\
\text { market }\end{array}$ & $\begin{array}{l}\text { Causality } \\
\text { and } \\
\text { Longitudinal } \\
\text { process }\end{array}$ \\
\hline No. in & 24,26, & $4,5,9$, & 39,40 & & \\
appendix & 28,29, & 10,11, & & & \\
& 36,37, & 12,13, & & & \\
& 38 & 19,20, & & \\
& 21,22, & & \\
& 25,27, & & \\
& 31,32, & & & \\
& 33,35, & & & \\
& 42 & & & \\
Total & 10 & 5 & 3 & & \\
\hline
\end{tabular}

Table 2. Classification of e-Business Models

*e-Business model No. 30 (Community Portal) was not classified.

In sum, the reviewed e-business models do not cover all aspects of business and can thereby not be labelled as business models. They do not cover causalities and the longitudinal process and activates and organisation, resources, and facto market are only part of some of the e-business models. Most of the e-business models address the offering level (19) and the market level (10). This may be a result of the focus on B2C (Business to consumer) that were the core of the 'dot.com' area, e.g. Amazon.com. The only ebusiness model that explicitly states that it is applicable to two parts of the business model is No. 24 (Brokerage model by Rappa 2002). This was the most surprising result of the analysis, since both Applegate (2001) and Timmers (1998) define business models as models that include costumers, products/services, and processes. However, Applegate (2001) describes how different e-business models interact with each other and how a firm may use several e-business models, but when she describes individual e-business model (see appendix) they seem to exist independent of each other. None of the reviewed e-business models addresses the causality between the components of an individual e-business model, the longitudinal process of a business model, or the management process.

\section{CONCLUSION AND RESEARCH IMPLICATIONS}

The business model concept is becoming increasingly popular, especially within e-business where several classifications of e-business models have been presented. However, the construct is not well defined, nor is there theory to support it (Porter, 2001). An analysis of some of the emergent ebusiness models was undertaken. The analysis was based on a generic 
business model, which integrates firm-internal aspects that transform factors to resources, through activities, in a structure, to products and offerings, to market and which is grounded in strategy theory. The analysis shows that most e-business models only address market (customers) and offering level (product and service). Few of the reviewed e-business models address internal activities or the control mechanisms of activities or the resources that are used to deliver a product or service to a market. Although this paper cannot claim to be exhaustive, it does provide reasonable insights into the state-of-the-art of e-business models. The results presented in this paper have several important implications. First, there is no doubt that e-business models research will increase and mature in the future. Secondly, a common vocabulary for e-business model and business models should be developed that addresses causality between the components and include the longitudinal process components. Future research should also be based on a sound theoretical framework and scientific method.

\section{REFERENCES}

Afuah, Allan, and Tucci, Christopher, Internet Business Models and Strategies: Text and Cases. Boston: McGraw-Hill, 2001.

Allen E., Fjermestad, J. E-commerce marketing strategies: integrated framework and case analysis. Logistics Information Management 2001; 14:14-23.

Amit, R., Schoemaker P.J.H. Strategic assets and organizational rent. Strategic Management Journal 1993; 14:33-46.

Amit, R., Zott, C. Value creation in e-business. Strategic Management Journal 2001; 22:493520.

Andreu, R., Ciborra, C. (1996) Core capabilities and information technology: an organizational learning approach. In Organizational Learning and Competitive Advantage, Bertrand Moingeon, Amy Edmondson, eds. London: Sage, 1996.

Applegate, L.M. Emerging e-business models: lessons from the field. HBS No. 9-801-172. Harvard Business School, Boston. 2001.

Barney, J. Strategic factor markets, expectations, luck and business strategy. Management Science 1986; 42:1231-1241.

Barney, J. Firm resources and sustained competitive advantage. Journal of Management 1991; 17:99-120.

Burt, Roland S. Structural Holes: the Social Structure of Competition. Cambridge: Harvard University Press, 1992.

Chakravarthy, B.S., Doz Y. Strategy process research: focusing on corporate self-renewal. Strategic Management Journal 1992; 13:5-14.

Cheng, E.W.L., Heng, L., Love, P.E.D., Irani, Z. An e-business model to support supply chain activities in construction. Logistics Information Management 2001; 14:68-77.

Cherian, E. Electronic business: the business model makes the difference. Proceeding of the Eight European Conference on Information Technology Evaluation, Dan Remenyi, Ann Brown, eds.; 2001 September 17-18; Oriel College, Oxford. 2001.

Eisenhardt, K.M., Sull, D.N. Strategy as simple rules. Harvard Business Review 2001; 79:107-116. 
Hedman, J., Kalling, T. (2001) The business model: A means to understand the business context of information and communication technology. Workingpaper 2001/9, www.lri.lu.se. School of Economics and Management, Lund University.

Hedman, J., Kalling, T. (2002) The business model: A means to comprehend the management and business context of information and communication technology. Proceeding of the Xth European Conference on Information Systems, Stanisław Wrycza, ed., 2002 June 6-8; Gdansk, Polen. 2002.

Mintzberg H. Patterns in strategy formation. Management Science 1978; 24:934-948.

Mintzberg, Henry, The Rise and Fall of Strategic Planning. Prentice Hall International: Hemel Hempstead, 1994.

Porter, Michael E. Competitive Strategy. Free Press: New York, 1980.

Porter, Michael E. Competitive Advantage. Free Press: New York, 1985.

Porter, M.E. Towards a dynamic theory of strategy. Strategic Management Journal 1991; 12:95-119.

Porter, M.E. Strategy and the Internet. Harvard Business Review 2001; 79:62-78.

Rappa, M. Business models on the web. http://digitalenterprise.org/models/models.html. Accessed on 19/03/2002.

Rayport Jeffrey F., Jaworski, Bernard J. Introduction to E-Commerce. Boston: McGrawHill/Irwin, 2001.

Schumpeter, Joseph, A. The Theory of Economic Development. Cambridge: Harvard University Press, 1934.

Timmers, P. Business models for electronic markets. Electronic Market 1998; 8:2-8.

Weill, Peter, Vitale, Michael R. Place to Space. Boston: Harvard Business School Press, 2001.

Williamson, Oliver, E. Markets and Hierarchies. Free Press: New York, 1975.

\section{APPENDIX}

\begin{tabular}{llll}
\hline Author & Applegate (2001) & Rappa (2002) & Timmers (1998) \\
\hline Dimensions & $\begin{array}{l}\text { Generic market role Digital } \\
\text { business } \\
\text { Platform }\end{array}$ & Unknown & $\begin{array}{l}\text { Value chain de- } \\
\text { construction } \\
\text { Interaction patterns } \\
\text { Value chain re- } \\
\text { construction }\end{array}$ \\
& & & e-shop (33) \\
Business & Focused distributor* & Brokerage (24) & e-procurement (34) \\
models & Retailer (1) & Advertising & e-auction (35) \\
& Marketplace (2) & $(25)$ & e-mall (36) \\
& Aggregator (3) & Infomediary & Third party marketplace \\
& Infomediary (4) & $(26)$ & $(37)$ \\
& Exchange (5) & Merchant (27) & Virtual communities (38) \\
& Portals* & Manufacturing & Value chain service \\
& Horizontal Portals (6) & Affiliate (29) & provider (39) \\
& Vertical Portals (7) & Community & Value chain integrators \\
& Affinity Portals (8) & $(30)$ & (40) \\
& & Subscription & Collaboration platforms \\
& Producers* & $(31)$ & (41) \\
& Manufactures (9) & Utility (32) & Information brokerage (42)
\end{tabular}




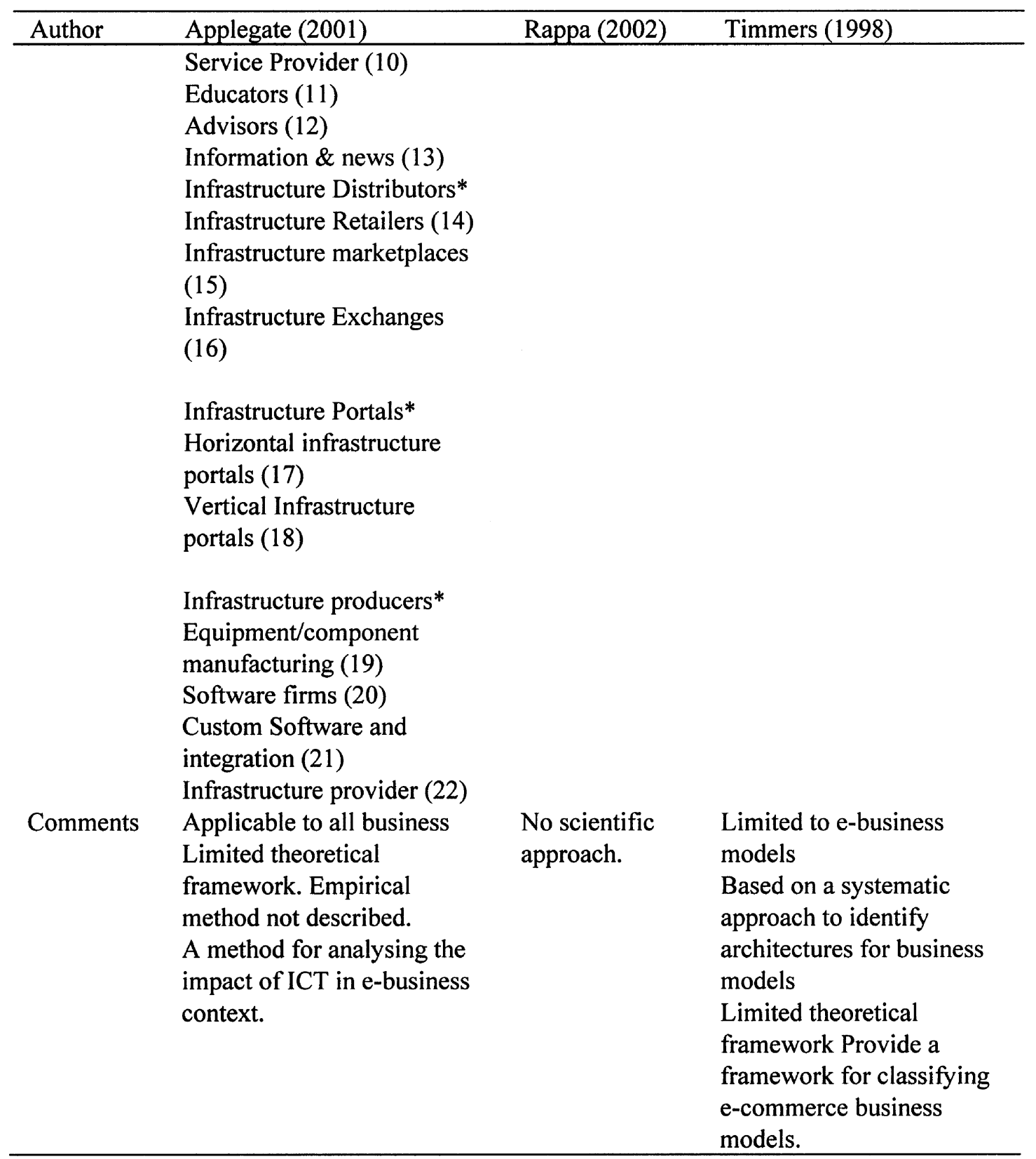

Table 3. Business Models

* Refers to Applegate's (2001) general categories. 